\title{
Paradigms as triggers of semantic change: Demonstrative adverbs in Catalan and Spanish*
}

\author{
Manuel Pérez Saldanya \\ Universitat de València \\ saldanya@uv.es
}

Received: May 30, 2015

Accepted: September 7, 2015

\begin{abstract}
This paper sets out to analyse the development of demonstrative adverbs of place in Catalan and Spanish. The main questions dealt with in this study are the following: (i) why two-term and three-term deictic systems often display a certain lack of stability so that diachronically two-term systems sometimes become three-term (as in old Catalan and Spanish) or, the other way round, three-term systems become two-term (like in late Latin and in Catalan during the modern era); (ii) if the most normal and expected development is for deictic systems to take on anaphoric values, why in the case of the adverb aqui ('near the speaker and/or addressee') in Catalan and the adverb ahi ('near the addressee') in Spanish the opposite process happens; (iii) what role is played in these changes by the functional and formal relations set up within the paradigms of nominal and adverbial demonstratives in each language.
\end{abstract}

Keywords: spatial deictic systems; adverbial demonstratives; anaphora; grammaticalisation, paradigm relationships.

Resum. El paradigma com a motor del canvi semàntic: els adverbis demostratius en català i castellà

L'objectiu d' aquest article és analitzar l'evolució dels adverbis demostratius de lloc del català i l'espanyol. Les principals preguntes que es plantegen en aquest treball són les següents: (i) per què els sistemes díctics binaris i ternaris mostren sovint una certa inestabilitat i diacrònicament els sistemes binaris es converteixen a vegades en ternaris (com s'esdevingué en el català i l'espanyol antics) 0 , a l'inrevés, els ternaris passen a ser binaris (com en el llatí tardà i en el català durant l'edat moderna); (ii) si allò més habitual i esperable és que els díctics assumeixin valors anafòrics, per què en el cas de l'adverbi aquí del català i l'adverbi ahí de l'espanyol es produí el procés invers; (iii) quin paper juguen en aquests canvis les relacions funcionals i formals que s'estableixen dins els paradigmes de demostratius nominals i adverbials de cada llengua.

Paraules clau: sistemes díctics espacials; demostratius adverbials; anàfora; gramaticalització, relacions paradigmàtiques.

* This study has been carried out as part of a research project supported by the Spanish Ministry of Economy and Competitiveness "Gramàtica del Català Modern (1601-1834)" (MINECO, Ref. FFI2012-37103) and by the Institut d'Estudis Catalans "Constitució d'un corpus textual per a una gramàtica del català modern" (Gcm; PR2015-S04-MARTINES). I thank Maria Josep Cuenca, José Ignacio Hualde, Josep Ribera and Gemma Rigau for fruitful discussions on several aspects dealt with this paper. 


\section{Table of Contents}

1. Introduction

2. Paradoxes and theoretical problems in the evolution of demonstratives

3 . The restructuring of the system of demonstrative adverbs from Latin

4. The formation of the three-term system in Catalan
5. The formation of the three-term system in Spanish

6. More recent developments in Catalan

7. Conclusions

References

Corpus

\section{Introduction}

The formation and development of demonstrative adverbs of place in Catalan and Spanish gave rise to a series of questions that are especially significant for a theory of linguistic change in general and of space deixis systems in particular. The aim of this paper is to analyse these topics in Catalan and compare the results with the development in Spanish within a Romance framework. In this paper, I also want to highlight the importance of paradigmatic relations, as triggers of semantic change and as a mechanism that can explain cases that, at least on the surface of it, threaten the unidirectionality of grammaticalisation processes.

Space deictics are referential expressions that allow places to be described (1a) or entities to be located $(1 b, c)$ in relation to the position occupied by the interlocutors of the speech-act. From a category point of view, a distinction is usually made between adverbial demonstratives, which function as locative adjuncts or complements (1a), and nominal demonstratives, which can function either as determiners (1b) or as neutral pronouns (1c) in languages like Catalan and Spanish. ${ }^{1}$

(1) a. Deixa les sabates aquí (Catalan) / Deja los zapatos aquí (Spanish) 'Leave the shoes here'

b. Posa't aquestes sabates (Catalan) / Ponte estos zapatos (Spanish) 'Wear these shoes'

c. Posa't això (Catalan) / Ponte esto (Spanish) 'Wear this'

The most widely used localisation parameter has to do with the proximity or distance from the place of utterance. It is usual that languages establish at least a two-way distinction, with two degrees of distance (proximal and distal), like English, which has two nominal demonstratives (this/that) and two parallel adverbs

1. Verbs of the type 'go' and 'came', also have a deictic meaning, which indicate movement in relation to the space occupied by the interlocutors. See Fillmore (1966) for the deictic meaning of these verbs in English, and Rigau (1976) and Cifuentes (2007) for the parallel verbs in Catalan and Spanish, respectively. On the category of demonstratives, see also Anderson \& Keenan (1985: 279-280) and Dixon (2003). 
(here/there). Also common are languages that present a three-way distinction, with three degrees (proximal, medial and distal), like Latin, which has three nominal demonstratives ( $h \bar{i} c / i s t e / i l l e)$ and different series of three parallel adverbial demonstratives ( $h \bar{l} c / i s t \bar{c} c / i l l \bar{c} c, h \bar{a} c / i s t \bar{a} c / i l l a \bar{c}$, etc.). Although it is not a universal property (Dixon 2003: 79-85), space deictics can also be used with an anaphoric function, and some nominal or adverbial demonstratives only have this function. ${ }^{2}$ The Spanish adverb ahi, for example, has a deictic function in (2a), where it denotes the place occupied by the addressee, and an anaphoric function in (2b), where it has Madrid as antecedent. Plus, the Catalan clitic $h i$ has a purely anaphoric function, as shown in example (2c), where it has Barcelona as antecedent.

(2) a. Quédate ahí.

'Stay there'

b. Fueron primero a Madrid y de ahi a Cuenca. (ahi= 'Madrid')

'They went first to Madrid and from there to Cuenca'

c. A Barcelona, fa temps que no $h i$ anem. ( $h i=$ 'Barcelona')

'We haven't been to Barcelona for a while'

The same as with other locatives items, adverbial demonstratives usually acquire more abstract temporal or notional values. ${ }^{3}$ For example, the Catalan adverb $a q u i$ 'here' has a temporal meaning in the construction d'aqui (a)... 'in x time' (3a) and a notional meaning in the consecutive constructions d'aqui que... 'hence' (3b).

(3) a. Tornarem d'aquí un moment

'We'll be back in a moment'

b. D'aquí que no ens digués res més

'Hence, he didn't tell us anything else'

\section{Paradoxes and theoretical problems in the evolution of demonstratives}

The development of demonstratives from Latin to the Romance languages of the Iberian peninsula poses a series of paradoxes and theoretical problems that are described below and that I shall attempt to address in this paper.

a) The first and most obvious question is related to the instability of two-term and three-term deixis systems. Table 1 shows the evolution of nominal demonstratives

2. In fact, corpus analysis shows that demonstratives frequently assume an anaphoric meaning. See Ribera \& Cuenca (2013) and Cuenca \& Ribera (2013) for a contrastive approach to demonstratives in fiction (English-Catalan, and English-Spanish, respectively).

3. On these temporal and notional extensions of the locative meaning, see Pérez Saldanya and Rigau (2011: § 4.3), for Catalan adverbial demonstratives, and Sánchez Lancis (1990:464-481), Maldonado (2013: 301-313) and RAE-ASALE (2009: § 17.8n, 179), for Spanish adverbial demonstratives. 
Table 1. Development of the system of nominal demonstratives from Latin to Spanish

\begin{tabular}{l|c|c|c|c}
\hline \multirow{2}{*}{ Deictic degree } & \multicolumn{4}{c}{ Linguistic stage } \\
\cline { 2 - 2 } & Latin & Late Latin & Old Spanish & Today's Spanish \\
\hline 1st degree & HĪC & \multirow{2}{*}{ (ecce/eccu) istu } & (aqu)este & este \\
\cline { 5 - 5 } 2nd degree & ISTE & & (aqu)esse & ese \\
\hline 3rd degree & ILLE & (ecce/eccu) illu & aquel & aquel \\
\hline
\end{tabular}

Table 2. Development of the system of nominal demonstratives from Latin to Catalan

\begin{tabular}{l|c|c|c|c}
\hline \multirow{2}{*}{ Deictic degree } & \multicolumn{3}{|c}{ Linguistic stage } \\
\cline { 2 - 2 } & Latin & Late Latin & Old Catalan & Today's Catalan \\
\hline 1st degree & HITC & \multirow{2}{*}{ (ecce/eccu) istu } & (aqu)est & aquest \\
2nd degree & ISTE & & (aqu)eix & \multirow{2}{*}{ aquell } \\
\hline 3rd degree & ILLE & (ecce/eccu) illu & aquell & aqu \\
\hline
\end{tabular}

from Latin to Spanish based on the masculine singular forms (and the masculine singular nominative in Latin). As the table shows, the Latin three-term system was reduced to a two-term system in Late Latin, due to the disappearance of the first degree demonstrative (HİC) and the semantic change of the second degree demonstrative (ISTE), which took on its value. ${ }^{4}$ At this stage, the demonstratives were usually reinforced by the deictic particle ECCE or the later ECCU, adopted in the Spanish reinforced forms (aquel, and in Old Spanish aqueste and aquesse that alternate with the simple forms este and esse respectively). Later on, the threeway system was reconstructed in Old Spanish by means of a form derived from the Latin demonstrative IPSE (esse or aquesse, modern ese), which initially had identifying and emphatic value (Pieroni 2010: § 3.5) and was used afterwards as a medial demonstrative. ${ }^{5}$ This three-term system has persisted to the present day in Peninsular Spanish, although some varieties of American Spanish seem be moving to a new two-way contrast. ${ }^{6}$

The development of Spanish is also shared by Portuguese and initially by Catalan. However, unlike Portuguese and Peninsular Spanish, in most Catalan varieties, a further reduction took place at a later stage and a two-way system

4. On the restructuring of Late Latin, see, amongst others, Väänänen (1968: 194-197), Iso Echegoyen (1974), Lloyd (1993: 155-156, 261-262, 446-448), Casanova (1993) and Roca (2009: 518-520).

5. It was reconstructed in the languages of the Iberian peninsula and partly from Occitan. Old Italian also has a three-term system and so does today's Tuscan (Renzi \& Vanelli 1995: 271, Vanelli 2010: 1248-1249).

6. This is the case of Argentinian Spanish and other varieties, in which the first degree is expressed by este, and the second either by ese or aquel. In this varieties the difference between ese and aquel is not one of distance but of register or genre, aquel being more formal and more contrastive than ese, but certainly not more distant. This recent development in American Spanish is not analysed in detail in this paper. On this subject, see Kany (1976: 320), Sedano (2003), RAE-ASALE (2009: $\S 17.2$ n), Guzmán \& Sáez (in press). 
has been adopted. As shown in table 2, in this new two-way system only the reinforced form aquest is kept to express the first degree, but not the parallel simple form est. ${ }^{7}$

The particular development of Catalan is even more surprising considering, as we shall see later on, that in this language the three-term system was documented much earlier than in Spanish and Portuguese.

b) The cyclical nature of the change shown in table 2 is not the only paradox in the development of Catalan. With the exception of Catalan, in all Romance languages, the place of the speaker (or near to it) and the place of the addressee (or near to it) can be distinguished by means of demonstratives. As is the case with English, in languages with a two-term system the distinction is established, respectively, by means of the proximal and distal demonstratives, as can be seen from the examples with demonstrative adverbs in (4).

(4) a. Put your shoes here; do not leave them there (English)

b. Metti le scarpe qui, non lasciarle li (Italian)

c. Pune pantofii aici; nu lasă-i acolo (Rumanian)

Likewise, in languages and dialects with a three-term system, the opposition is set up by means of the proximal and medial demonstratives, respectively, as shown in the examples with demonstrative adverbs in (5). ${ }^{8}$

(5) a. Pon los zapatos aquí; no los dejes ahí (Spanish)

b. Põe os sapatos aqui; não os deixes aí (Portuguese)

c. Metti le scarpe chi; un lascialle costi (Tuscan)

d. Posa les sabates ací; no les deixes ahí (Catalan from Valencia)

e. Mets les chaussures ici, ne les laisse pas là (French)

It is only in Catalan that this distinction cannot be established by means of demonstratives, as shown in (6), where the demonstrative adverb aqui is used in both cases.

(6) Posa les sabates aquí; no les deixis aquí (Catalan)

In English and in all Romance languages, with the exception of Catalan, the first degree describes the speaker's deictic space (the place that the speaker occu-

7. The three-term system has been preserved in varieties of Catalan spoken in Valencia and Aragon with the following nominal demonstratives: est(e) / eix (e) / aquell.

8. The third degree in Spanish uses the adverb alli (or allá), in Portuguese ali, in the Catalan used in Valencia allí (or allá), in Tuscan alì (or là) and in French là-bas. 
pies or near to it) and the other or the other two degrees are defined by negation of it. According to this, in two-term system languages, the second degree indicates distance from the speaker and can therefore denote the addressee's deictic space (the place that the addressee occupies or near to it), as shown in figure 1.

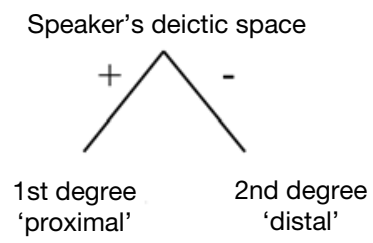

Figure 1. More usual two-term deictic system.

In three-term system languages, the intermediate degree expresses proximity but excludes the place of the speaker, that is, it indicates medial proximity, which is frequently associated with the addressee's deictic space. ${ }^{9}$ The third degree is defined negatively in respect of the second and indicates distance both from the speaker and from the addressee, as shown in figure 2.

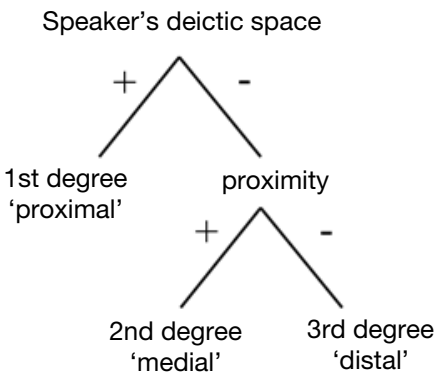

Figure 2. Three-term deictic system in Romance languages.

Only in Catalan does the first degree refer to the deictic place of both the speaker and the addressee, and the second degree, which is negatively defined, indicates distance in relation to both, as shown in figure 3 .

9. For some authors the second degree of the three-term system is identified with the addressee's deictic space, as opposed to the first degree, which describes the speaker's space (Bello 1847: § 254, Vanelli \& Renzi (1995: $§ 2.2 .3$ ), Wheeler et al 1999: $§ 6.2-3$ ). Others, on the other hand, argue that it describes an intermediate space between the nearness of the place occupied by the speaker and the distance (Hottenroth 1982; Anderson \& Keenan 1985: 282; Eguren 1999: § 14.3.2.1; Brucart 2002: $\S 7.4 .2)$. In this paper we take the latter perspective, but with a clarification put forward by Saragossà (2004: $\S 3.2 .1$ ), which is historically relevant: the fact that the second degree indicates proximity, like the first, but with the difference that it excludes the speaker and is therefore frequently associated with the addressee's space. 


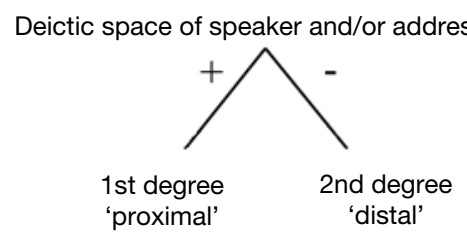

Figure 3. Two-term deictic system in Catalan.

c) The development of the deictic systems in Romance languages gives rise to a third paradox related to the supposed unidirectionality of grammaticalisation processes. Lexemes or constructions that are grammaticalised take on a grammatical value, or a higher grammatical value than they had at first. This usually occurs in conjunction with other changes, specifically in conjunctions with a greater syntactic fixation, an increased frequency of use, a more abstract and subjective meaning and, in certain cases, a phonic erosion. ${ }^{10}$

One of the classic examples of the processes of grammaticalisation and unidirectionality of change is the development of the Romance article based on the third degree nominal demonstrative (7a). In this case grammaticalisation is translated: (i) semantically in the step from a deictic value to a more grammatical anaphoric or identifying value, (ii) syntactically in fixation in the prenominal position, and (iii) formally in a strong phonological erosion associated with the cliticisation process. The same change from a deictic meaning to an anaphoric one, and to a greater syntactic fixation and formal erosion can be seen in the Romance languages with the formation of third person pronominal clitics based on Latin demonstratives. These clitics usually derive from the distal demonstrative (7b-d), but also from the proximal demonstrative in the case of the Catalan neutral pronoun ho (7e).

(7) a. ILLUM 'that-accusative-masculine-singular' > él:o > elo > el (Spanish) / lo $>$ el, l' (Catalan) 'the'

b. ILLUM 'that-accusative-masculine-singular' $>$ él:o $>$ elo $>$ lo (Spanish) / lo $>$ el, lo, l', 'l (Catalan) 'him'

c. ILLAM 'that-accusative-feminine-singular' $>$ él:a $>$ ela $>$ la (Spanish) / la, l' (Catalan) 'her'

d. ILLī 'that-genitive-singular' > él:i > eli > le (Spanish) / li (Catalan) 'to him/ her'

e. Hōc 'this-accusative-neuter-singular' > ho (Catalan) 'it'

The development of the system of demonstratives from Latin to Romance languages of the Iberian peninsula produced, at least apparently, a counter-example

10. On the concept of grammaticalisation and the unidirectionality of change, see, amongst others, Hopper \& Traugott (1993: § 1), Traugott (1995, 2003), Company (2003) and Cuenca (2009). On the development of demonstratives into grammatical markers, see also Diessel (2006: 476-481). 
to the unidirectionality of the processes of grammaticalisation. ${ }^{11}$ In fact, in the case of demonstratives that take on intermediate degree value (for example ese and ahi in Spanish) the change goes from an identifying and anaphoric value to deixis, and in the case of $a h i$ it also involves an increase in phonological content:
a. IPSUM ('self', '((s)he/it) self') > ese 'that'
b. IBİ ('the aforementioned place') $>$ hi $>$ ahí 'there'

\section{The restructuring of the system of demonstrative adverbs from Latin}

Latin displays a rich system of demonstrative adverbs which, in addition to the deictic or anaphoric distinctions associated with the root, enabled the expression of a number of spatial notions signalled by endings, as can be seen in table $3 .{ }^{12}$

The spatial notions associated with the endings blurred with the evolution from Latin to Romance and finally became expressed by the presence or absence of locative prepositions. ${ }^{13}$ As a result, some of the series eventually disappeared or changed their initial meaning. Spanish and Catalan have kept no adverbs derived from the series in $-\overline{\mathrm{U}} \mathrm{C} / \overline{\mathrm{O}}$, and those derived from the series in -INC/INDE eventually disappeared, with the exception of the clitic en in Catalan (INDE >ne > en, ne, $n$ ', 'n), which preserves its original meaning (En vinc 'I come from there') but has also taken on other values related to the preposition $d e$ 'from, of' (partitive, genitive, etc.). Both languages have retained forms that derive from the series in $-\bar{I}(\mathrm{C})$ and $-\overline{\mathrm{A}}(\mathrm{C})$. In Spanish, the adverbs in $-i(a q u i$, ahi and alli) refer to more specific and objective locations, or locations conceived as points; similarly, the adverbs in -á (acá and allá) refer to more vague and subjective locations, or locations conceived as areas (Carbonero 1979: 73-76; Hottenroth 1982: 135; Sedano 1994, 2000, 2001; Eguren 1999: § 14.4.2.1; RAE-ASALE 2009: § 17.8f; Maldonado 2013). ${ }^{14}$ The same holds for Catalan, but the distinction is much less sharp, with the opposition between adverbs in $-\dot{i}$ and in $-\dot{a}$ only being kept in adverbs that indicate distance (alli $i$ and

11. This anomaly is referred to explicitly in the grammar of the RAE-ASALE $(2009 \S 17.2 . \tilde{n})$ when it explains the semantic change undergone by the Latin demonstrative ipse from the identifying value to the second degree deictic in peninsular Romance languages, saying: "constituye un proceso más anómalo desde el punto de vista tipológico que el contrario (es decir, la pérdida del valor deíctico de los demostrativos)".

12. See Ernout (1953: $\S 106,139)$, Monteil, (1992: 276-278) and Bassols (1956: $\S 162)$ and others.

13. Like in English and in many other languages (Dixon 2003: 70), the locative and the goal are expressed without preposition, and it is the verb that enables an understanding of whether the adverb indicates location (Vive alli '(s)he lives there') or goal (Irá alli '(s)he will go there'). The other values, however, are expressed by means of the adverb preceded by a preposition, as in this case the same verb can be combined with different expressions of place: Vino \{desde/por\} alli ('(s) he comes $\{$ from/through $\}$ there').

14. Most authors describe the opposition in terms of specific/vague locations (i. e. points and areas). However, in an interesting paper on the opposition between aquí and acá, Maldonado (2013) considers that this difference is derived from a more basic one based on degrees of "objectivity". From this point of view, aqui involves a medium degree of subjectivity or quasi-objectivity that marks nearby areas and acá involves a close nearness that determines a greater degree of subjectivity. 
Table 3. Latin demonstrative adverbs

\begin{tabular}{|c|c|c|c|c|c|}
\hline \multirow{2}{*}{\multicolumn{2}{|c|}{ Referential value }} & \multicolumn{4}{|c|}{ Spatial notion } \\
\hline & & Locative 'Iocation' & Adlative 'goal' & Perlative 'path' & Ablative 'source' \\
\hline \multirow{3}{*}{ Deictic } & 1st degree & HīC & HŪC & $H \bar{A} \mathrm{C}$ & HINC \\
\hline & 2nd degree & ISTĪC & ISTŪC & ISTĀC & ISTINC \\
\hline & 3rd degree & ILLĪC & ILLŪC & ILLĀC & ILLINC \\
\hline \multicolumn{2}{|c|}{ Anaphoric } & IBĪ & EŌ & $E \bar{A}$ & INDE \\
\hline
\end{tabular}

Table 4. Demonstrative adverbs in Old Spanish

\begin{tabular}{l|l|l}
\hline \multicolumn{2}{c|}{ Referential value } & \multicolumn{1}{c}{ Adverbs } \\
\hline \multirow{2}{*}{ Deictic } & 1st degree & ECCU-HĪC > aquí \\
\cline { 2 - 3 } & 2nd degree & ILLĪC > allí \\
\hline Anaphoric & IBĪ > y (or hi) \\
\hline
\end{tabular}

allà), but not in the entire linguistic domain, as alli is used purely for literary purposes in some areas (Pérez Saldanya \& Rigau 2011). ${ }^{15}$

This study focuses basically on the derivatives of Latin adverbs in $-\bar{I}(\mathrm{C})$, as they are the only ones that reconstruct the two-way system of Late Latin in a new three-way system. ${ }^{16}$ As with nominal demonstratives, adverbial demonstratives also experienced a simplification of the deictic system in Late Latin, which entailed the loss of second degree adverbs (ISTİC, ISTĀC, etc.). This two-term system was initially retained in both Spanish and Catalan, with Old Spanish having a simpler system than Old Catalan. As shown in table 4, the system in Old Spanish was reduced down to three adverbs: two deictic (aqui and alli) and one anaphoric ( $y$, also spelled $h i$, which would later give rise to $a h i$ ). The first degree adverb comes from the Latin first degree adverb with the reinforcement ECCU, whereas the other two forms come from the corresponding Latin adverbs.

The system of Old Catalan was more complex, as it includes five adverbs distributed in a full (or stressed) series plus another clitic (or unstressed) series. Three of these forms derive from the Latin first degree adverb (Hīc), one without reinforcement $(h i c)$, one with the reinforcement ECCE $(a c i)$ and a third one with the reinforcement ECCU (aqui). ${ }^{17}$

15. The same difference is found in Italian, which presents two parallel series of adverbs: qui and $l i$, on the one hand, and quà and là, on the other (Vannelli \& Renzi 1995: § 2.2.2).

16. The fact that the three-way system was reconstructed in the -[i] adverbs and not in the -[á] adverbs is related to the meaning of each series and, specifically, with the fact that the three-way distinction is easier in those adverbs that refer to more specific locations, than in adverbs expressing more vague and subjective locations.

17. On this point Catalan is presented as a bridging language between Gallo-Romance and Iberian Romance languages: like those ones, they present forms derived from adverbs with the oldest reinforcement ECCE, and like these ones, they also have forms derived from adverbs with the latest reinforcement ECCU. 


\section{The formation of the three-term system in Catalan}

Apart from the clitic hic in Catalan, which fell into disuse early on, the main difference between Old Catalan and Old Spanish has to do with the existence of a full adverb in Catalan (aqui) functionally parallel to the clitic $h i$ (or en depending on the spatial notion). ${ }^{18}$ This difference can explain why the three-way deixis system could be reconstructed earlier in Catalan than in Spanish. In all medieval texts, aquí is documented mainly with an anaphoric function, which, as shown in table 5, seems to be the original one. This is the case in (9), where aqui is used twice, in both cases preceded by a locative phrase that functions as antecedent.

(9) dix que menà los àsens a casa d'en Berenguer Dalmau e lexà'ls aquí; e la dona d'en Berenguer Dalmau donà-li del vin de la companya e begé més de 'IV· taces, e enaprés anà-se'n a la taverna d'en Tamarit, e begé aquí de vin [...] e enbriagà's (Clams: 122).

'he said that he took the donkeys to Berenguer Dalmau's house and left them there, and Berenguer Dalmau's wife gave him wine from the company and he drank more than four glasses and then he went to Tamarit's tavern, and drank wine there and got drunk'

As indicated above, in this anaphoric function, aqui coincides, therefore, with the clitic adverbs $h i$ and en. However, its tonic nature makes it the most emphatic option from a communicative point of view. In (10), for example, the three adverbs have the same locative phrase as antecedent (la nostra posada), but aquí is used in the sentence in which the place mentioned is most relevant: the one indicating that Infante Pere has had to stay overnight in the besieged inn. ${ }^{19}$

(10) totes les gents de la villa de Murvedre se van abocar entorn la nostra posada $\mathrm{ab}$ armes, per manera que null hom no $n$ podia exir que no $n$ fos per ells reconegut qui era; axí que 1 infant En Pere, qui $y$ fo vengut, no $n$ poch exir, ans hagué aquí a romandre a jaure (Epistolari: 92-93).

'All the people from the town of Morvedre arranged themselves around our inn with weapons, so that nobody could leave there without being recognised; so the Infante Don Pedro, who had gone there, could not leave there, but had to stay there to sleep'

Together with this anaphoric function, the adverb aqui was soon documented with a deictic value related to the place occupied by the addressee, or a space close to the speaker that could be used to refer to the space of the addressee as well in the event that the addressee was close to the speaker. The first examples that I have

18. The adverb en has the value of source, and the adverb hi, the other spatial notions (location, goal, path).

19. The distinction would therefore be similar to the one set up between the use of stressed or clitic personal pronouns in the cases where they alternated in the old language; for example, dix aixo a ell 'he said that to him' (with the stressed ell) compared to dix-li aixo 'he told him that' (with the unstressed $l i$ ). Or in today's language between the use of double clitics with a stressed pronoun or on their own: Li va dir això a ell 'he said that to him' compared to Li va dir això 'he told him that'. 
Table 5. Demonstrative adverbs in Old Catalan

\begin{tabular}{l|l|l|l}
\hline \multirow{2}{*}{ Referential value } & \multicolumn{2}{c}{ Adverbs } \\
\cline { 3 - 4 } & \multicolumn{1}{c|}{ full } & \multicolumn{1}{c}{ clitic } \\
\hline \multirow{2}{*}{ Deictic } & 1st degree & ECCU-HĪC $>$ ací & HITC > hic \\
\cline { 2 - 4 } & 2nd degree & ILLITC $>$ allí & --- \\
\hline Anaphoric & ECCU-HĪC $>$ aquí & IBĪ $>$ hi $($ or $\mathrm{y})$ \\
\hline
\end{tabular}

documented of this deictic use date back to texts from the second half of the 13th century or the first half of the 14th century. In these examples the deictic value is strongly linked to the situational context and to the type of speech-act, as shown in (11). In (11a) aqui seems to refer the space of the hearer, excluding the speaker. In (11b-c), aqui denotes a space close the speaker that is occupied by the addressee.

(11) a. e sobre azò él vi ·I· ome e dix-li:

— «[Qui] està aqui?».

E anc aquel om no sonà mot, e él dix-li altra vegada:

— «Qui està aqui?». (Alcoi: 24)

'and he saw a man and said to him: «Who's there?» and the man gave no answer, and he said again: «Who's there?»"

b. E, entre aquestes paraules, él s'adormí. E vesec Sent Marc qui li vénc e·s pausà costa lo seu lit, e ausí · I vou, a él dient: —Què fas aquí, March? (Vides: 422)

'And, with these words, he fell asleep. And he saw that St Mark came to him and stood next to his bed, and he heard a voice that said to him, «what are you doing (t)here Mark?»'

c. E quant la sancta ayçò viu, levà's, e ab cara irada e ab grans critz li dix: «Ix d'él, mesquín, ix-ne!» $\mathrm{E} \cdot 1$ demoni li respòs: «E, si d'él isc, un entraré?» E per aventura avia aquí $\cdot \mathrm{I} \cdot$ porquet, qui paxia aquí. «Ix d'aqui»), dix la sancta, «e entra en aquest porc!» E aytan tost desemparà l'ome, e entrà en lo porc, e aucís-lo, e anà-sse'n. (Diàlegs: 49v)

'And when the saint saw this, she got up and with an angry face and loud shouts she said to him «Leave him, wretch, leave! ». And the devil replied «And if I leave him, where shall I go?». And it so happened that there was a piglet there, grazing. "Get out of $(t)$ here!» said the saint, "and enter that pig!». And straightaway it left the man and entered the pig, and he killed it and it went away'

The above examples are probably contextual deictic uses, similar to those that can be taken on by other anaphoric elements in contexts where the addressee is being questioned or asked something. This is what happens, for instance, in today's Catalan with the anaphoric clitic $h i$ in cases like the one in (12a), with the clitic referring to a box held by the addressee, or the example in (12b), with the clitic referring to a document that the addressee is reading. Likewise in $(12 \mathrm{c})$, where the clitic is in 
correlation with the deictic aqui ('proximal' to the speaker or addressee in modern Catalan) and it denotes the place of the addressee or a space including it. ${ }^{20}$

(12) a. Què $h i$ vols posar?

'What do you want to put there?'

b. Què hi diu? 'What does that say?' (lit. 'What there says')

c. Què hi fas, aqui?

'What are you doing there?'

Therefore, the fact that in Old Catalan the anaphoric adverb aqui can take on this type of contextual deictic values is not surprising. But it is surprising that these values eventually become lexicalised and produce a change that goes from anaphora to deixis. A factor that favours this fixation is the parallelism between space deixis and person deixis, and more specifically the fact that each space deictic is associated with one of the three grammatical persons. However, more specific factors must be added to this general factor in order to explain why the three-term deixis has not been reconstructed in all Romance languages. To account for these differences, paradigmatic relationships should be taken into account, and in particular, the analogical pressure that other elements in the adverbial demonstrative paradigm can exert to a specific anaphoric form within each language. As table 6 shows, at first aqui was linked to $h i$ (and en) by their anaphoric function, but also with aci and allí, for their morphological structure and their syntactic distribution.

This formal and distributional proximity with both aci and allí, together with the fact that these two deictic adverbs also had anaphoric values, ${ }^{21}$ undoubtedly contributed to the contextual deictic values of aqui becoming fixed quite quickly. As table 7 shows, in this new system, aqui keeps its initial anaphoric function but incorporates the deictic meaning of medial distance, i.e. the possibility of denoting

20. In fact, these deictic uses of anaphoric items are consistent with some cognitive interpretations of deictic and anaphoric reference (cf. Ariel 1990; Cornish 1999) according to which what is distinct between deixis and anaphora is not the 'geographical' origin of reference, i.e. either exophoric in the former or endophoric in the latter. Thus, Cornish (1999: 22) states that "where they crucially differ [...] is in the fact that deictic reference has the effect of drawing an element of the utterance or discourse context to the addressee's immediate attention, whereas anaphoric reference presupposes that his or her attention is already focused on the intended referent". For a review of this approach to modes of reference based on attentional states and degrees of referent activation, see Ribera (2008: 89-94).

21. If aqui has a non-marked anaphoric value and is limited to retaking a previous locative, aci adds a subjective proximity value (i) and alli a distance value, as shown respectively in the following examples:

(i) E altre dia passam per Uclés, que·ns convidà lo maestre; e el dia que partim d'ací perferíns lo maestre que iria ab nós ab $\cdot \mathrm{C} \cdot$ cavallers. (Fets: 341 )

'And another day we went to Uclés, as the Maestre invited us; and the day we left here the Maestre offered to go with us with a hundred knights'

(ii) e puys hach sabudaria que al port d'Aygües Mortas éran. E quant no les trobà alli, no se'n volch pus destorbar e tornà-sse'n al port de Cadaqués. (Crònica: 123)

'And afterwards I found out that they were in the port of Aigües Mortes. And as he could not find them there, he did not want to delay further and he returned to the port of Cadaqués' 
Table 6. Adverbs in [í/i] in Old Catalan (two-term deictic system)

\begin{tabular}{c|c|c|c}
\hline Deictic & \multicolumn{3}{c}{ Anaphoric } \\
\hline \multicolumn{2}{|c|}{ Full form } & Clitic \\
\hline ací & & aquí & hi \\
\hline allí & & & \\
\hline
\end{tabular}

Table 7. Adverbs in [í/i] in Old Catalan (formation of the three-term deictic system)

\begin{tabular}{c|c|c}
\hline Deictic & \multicolumn{2}{c}{ Anaphoric } \\
\hline \multicolumn{2}{|c|}{ Full form } & Clitic \\
\hline ací & aquí & hi \\
\hline allí & & \\
\hline
\end{tabular}

the space of the addressee as opposed to the space of the speaker. This deictic use emerges in emphatic contexts, where the addressee's space needs to be differentiated from that of the speaker and so it connects perfectly with the emphatic nature of aqui in respect of the anaphoric variant $h i$.

In 14 th century texts, the deictic value of aqui seems to have become fully conventionalised already. Clear signs of this fixation are the relative frequency with which it is documented and the fact that in quite a few cases aqui contrasts with the first degree adverb aci, both in dialogues (13a), and in epistolary texts, in which aci denotes the place of the letter writer and aqui the place of the person the letter is being sent to $(13 \mathrm{~b}, \mathrm{c})$.

(13) a. "Bé siau venguda, na Cristòfola! Què féts aqui?" E la dita Cristòfola dix: "Venia veure madona Trialles e esper-la aci". E ell deposant dix: "Via! anfretant venits aci", dient-ho de la sua cambre. (Cavaller: 178)

'Welcome, madam Cristófola! What are you doing there? And the aforementioned Cristófola said "I came to see madam Trialles and I'm waiting for her here". And the declarant said "Well, in the meantime come here", referring to his bedroom.'

b. Ffas-vos saber, senyor, que lo senyor rey vos tramet aquí dues galees per trametre a mi aci en Barchinona aquelles $\cdot \mathrm{VII} \cdot$ mille lliures barchinoneses (Reintegració: 169)

'I assure you, sir, that the King sent you there two galleys to bring (me) here to Barcelona those seven thousand pounds'

c. E açò comanam als desús dits, e a vós ab ells ensemps, per ço com vosaltres, qui aquí sots, veets e conexets mils què se'n deu fer e què n'és pus expedient als afers, que no fem nós ací. (Epistolari: 172)

'And we arranged this with the aforementioned and with you at the same time, for you who are there. You see and know better what has to be done and what is more suitable for business, than we can here' 
A third sign of the fixations of the deicitic value is the fact that aqui is used not only to express the addressee's deictic space but also to indicate the medial proximity to the speaker, as shown in the two appearances of aqui in (14) respectively.

(14) Axiu d'equy, que veus aquy òmens, non ssé qi·s ssón! (Cort: 207)

'Come out of there, there are men there, I don't know who they are!'

If at first the deictic value is derived from a contextual use associated with the addressee, its use for expressing medial proximity to the speaker looks more like a semantic broadening, which suggests a greater degree of fixation of the deictic value.

\section{The formation of the three-term system in Spanish}

As indicated above ( $§ 3$ ), the initial system of demonstrative adverbs in Spanish had just one anaphoric element (the adverb $y$ ). This can explain why the three-term system took a little longer to appear in Spanish than in Catalan. The adverb $y$ could be used with a contextual deictic value, but its formal and functional differences compared to the deictic adverbs (aqui and alli) ${ }^{22}$ hindered this use from becoming conventionalised. Therefore, the reconstruction of the three-term system in Spanish required the previous appearance of the analogical variant ahi of the adverb $y$, with the initial $a$ that is characteristic of various demonstratives, and formally links this adverb to the deictics aqui and alli, as shown in table 8. Note, on the other hand, that if $y$ was initially a stressed form, the appearance of the disyllabic ahi brought on the loss of tonicity of $y$, which progressively became a clitic adverb

The first documentary evidence of the analogical form ahi is found in 14th century texts or in copies from this period (Gutiérrez \& Pascual 1995, Pascual 2010). As indicated in table 8, at first, ahi was used with the anaphoric value of $y$, as in (15), where it has la plaça ('the square') as antecedent.

(15) Abaxé más la palabra, díxel que en juego fablava / porque toda aquella gente de la plaça nos mirava; / desque vi que eran idos, que omne aý non fincava, / començél dezir mi quexura del amor que me afincava. (Buen Amor: 166) 'I lowered my voice, I told him I was joking / because all those people in the square were looking at us; / when I saw they had gone, that nobody was left there / I started to tell him my amorous complaints'

Later the anaphoric value was joined by a deictic value related to the place of the addressee by means of a process similar to the one already described for the

22. Note that the adverb $y$ in Spanish is halfway between the adverbs hi and aqui in Catalan. Just like this one $y$ can function by occupying the position of an adjunct or function as a complement to a preposition, as shown by the following example: "non avié ý aún carrera fecha ninguna, ca nunca andudiera omne por y'" (General Estoria: 12) "They had not done any path there, because nobody had ever been there'. But it also displays symptoms of the start of the cliticisation process that will be consummated later. 
Table 8. Adverbs in [í/i] in Old Spanish (documented in 14th century)

\begin{tabular}{|c|c|c|}
\hline Deictic & \multicolumn{2}{|c|}{ Anaphoric } \\
\hline \multicolumn{2}{|c|}{ Full form } & Clitic \\
\hline aquí & \multirow{2}{*}{ ahí } & \multirow{2}{*}{$y$} \\
\hline allí & & \\
\hline
\end{tabular}

adverb aqui in Catalan (see $\S 4$ ). The first clear examples are found in works from the 15th century (Corominas \& Pascual, 1980-1991: s.v ahí; Sánchez Lancis, 1990: 58-60, Terrado 1990; Company \& Espinosa 2014: 177), a time when the deictic value seems to be fully conventionalised: ${ }^{23}$

(16) a. Dicho e fecho; el buen onbre sabyo tomó la anpolla e púsola en una ventana donde ella la viese. E luego dixo ella: “¿Qué pones $a y ́$, marido?” (Corbacho: 152)

'Said and done; the good wise man took the bottle and put it in a window where she would see it. And then she said "What are you putting there, husband?'

b. - Vós non dezides verdad, que aquellos que vós dezides, e yo con ellos, somos aquí juntados por serviçio del rey, e somos sus servidores, tanto como vosotros, esos que aý estades. (Victorial: 510)

'You are not telling the truth, as those you talk about, and I with them, are here together at the king's service, and we are his servants, as are you, who are there.'

d. MELIBEA. ¿Qué haces aý escondida, loca?

LUCRECIA. Llégate aquí, señora; oyrás a tus padres la priessa que traen por te casar. (Celestina: 303)

'MELIBEA. What are doing hiding there, crazy woman?

LUCRECIA. Come here madam; you will hear how your parents are in a hurry to marry you off.'

Note also that, to the extent that ahi is a reinforced variant of $y$, pushed the latter into disuse. As a consequence, there is a double change in the system, as the conventionalisation of the deictic value in the adverb ahi runs parallel to the loss of vitality of $y$, which undergoes the process of cliticisation mentioned above that ends up with its morphological reanalysis in certain verbal forms (hay 'there is', soy 'I am', voy 'I go' and estoy 'I am/stay'). According to Company \& Espinosa (2014: 130-131, 198-199), this loss of vitality increased all the way through the 14 th century, and became very prominent in the two first decades of the 15 th century, although the adverb was still retained in some works until well into the 16th

23. Portuguese underwent a similar development to Spanish with the development of the adverb ai, which also came from the anaphoric $y$ (Teyssier 1981). 
century. So, unlike Catalan, the Spanish system was reduced to the full forms (aquí, ahi and alli) and has not maintained any specific anaphoric adverb.

\section{More recent developments in Catalan}

Once the three-term system had been reconstructed and the adverb $y$ had disappeared, the Spanish system remained in place with no major changes up to the present day in Peninsular Spanish. ${ }^{24}$ On the contrary, a more complex development took place in Catalan, since, as has already been described in $\S 2$, the three-term system has disappeared in most Catalan varieties, giving way to a two-term system in which aquí indicates proximity to the speaker and/or addressee and allà (or alli) expresses distance. This change is already well documented in 17 th century texts, as shown in the examples in (17): in (17a) both aqui and aci refer to the speaker's deictic space, and in (17b) aqui is used to refer deictically to the point in the text where the adverb appears.

(17) a. aquí ahont jo só, debaix de mi ý de mos peus, és lo acte; que dit Gelmar Bonsoms, notari, m'o à dit en lo infern, hont ell està. Desfeu estas rajolas que estan assí, que, des de la setena rajola fins a la dotzena de la paret, se trobarà lo manual. (Viatge: 236 )

'Here where I am, under me and my feet, is the document; that the aforementioned Gelmar Bonsoms, notary, told me in hell, where he is. Break these tiles that are here, as between the seventh and the twelfth tile in the wall the document will be found'

b. Y dire aqui una cosa la qual yo he considerada, y crec que molts la hauran advertida (Geografia: 245)

'And I will say here something I have considered and that I think many will have already guessed'

In order to explain this restructuring of the system, both general factors and specific factors should be taken into account. The former are related to the nature of the deictic systems, independently of the forms of each specific language. The latter depend on the specificities of the demonstrative paradigm in Catalan.

\subsection{General factors in the restructuring of the Catalan system}

In terms of general factors, the possibility of using a second degree deictic (medial) with first degree value (proximal) can be favoured by the nature of space deictic items and three-way oppositions. Firstly, space deictics are opaque and elastic in nature. They are opaque because their mere utterance does not ensure that the referent can be identified (Eguren 1999: $§ 14.2 .2$ ), and they are semantically elastic because they can be used to describe more or less extensive places. This means

24. For the specificities of American Spanish varieties with a two-term deictic system, see footnote 25 below. 
that a first degree adverb can denote the speaker's space compared to that of the addressee (aqui donde estoy sentado 'here, where I am sitting'), but also a wider place including them both (Aquí, donde estamos, hace mucho calor 'Here, where we are, it's very hot').

In addition, in three-term systems, the opposition between the first degree and the second degree is objective if it is associated with the place occupied by the speaker and the addressee, respectively, but not if two degrees of proximity are expressed: immediate and medial, respectively (Eguren 1999: $§ 14.4 .2$; Brucart 2002: 1492-1493).

The two factors mentioned above can undoubtedly contribute to the loss of opposition between proximity (first degree) and medial proximity (second degree), and this explains the possibility that a deictic expressing medial proximity changes to indicate simple proximity. This change, in fact, does not only affect the demonstrative adverb aqui in Old Catalan. The nominal demonstrative ISTE (see $\S 2$ ) underwent the same change in Late Latin and can be found today in certain uses of the French adverb là and of the determiner esse in Brazilian Portuguese. As for French, là keeps the value of intermediate distance in comparison to ici, but it is used in certain contexts with the value of the proximal demonstrative (18a). Similarly, in Brazilian Portuguese, the second degree nominal demonstrative esse has colloquially displaced the first degree nominal demonstrative este, and is reinforced with aqui ('here') when reference is made to immediate proximity (18b).

(18) a. _-Vous ne sortez pas? —Non, non, non, on bouge pas..., on reste là (Kleiber 1995: 13)

'Are you not going out? No, no, no, we are not moving... we are staying here (lit. there)'

b. Essa mesinha aquí ele recebeu de um amigo de Portugal (Jungbluth 20042005: 90)

'This table here (lit. that table here), he received it from a friend in Portugal'

\subsection{Specific factors in restructuring the Catalan system}

The fact that the reduction of the system was favoured by the nature of the space deixis and three-term systems does not fully explain why this reduction took place in Catalan and not in Peninsular Spanish. To justify these differences, once again, the specific paradigmatic factors of Catalan need to be taken into account. As shown in table 9, at first, aci and aquí were formally linked with other demon-

Table 9. Demonstratives in Old Catalan

\begin{tabular}{l|l|l|l|l|l}
\hline \multicolumn{2}{c|}{ Determiners } & \multicolumn{2}{c|}{ Pronouns } & \multicolumn{2}{c}{ Adverbs } \\
\cline { 1 - 3 } (ai)cest & (aqu)est & \multirow{2}{*}{$*--$} & açò & ací & ça \\
\cline { 1 - 2 } (ai)cell & aquell & & allò & allí & Ilà (> allà) \\
\hline n--- & (aqu)eix & ço & això & aquí & --- \\
\hline
\end{tabular}


Table 10. Nominal and adverbial demonstratives in Today's Catalan

\begin{tabular}{l|c|c|c}
\hline \multirow{2}{*}{\multicolumn{1}{c}{ Deictic value }} & \multicolumn{3}{c}{ Category } \\
\cline { 2 - 4 } & Determiners & Pronouns & Adverbs \\
\hline Proximal (to Sp. and/or Add.) & aquest & això & aquí \\
\hline Distal & aquell & allò & allà / allí \\
\hline
\end{tabular}

strative determiners or pronouns. The adverb aci had a formal correlation with the other demonstratives that had arisen from the reinforcement ECCE, namely, the determiners (ai)cest and (ai)cell, the deictic pronoun $a c ̧ o$, the phoric pronoun ço and the adverb ça. The adverb aquí, on the other hand, was correlated with determiners with the reinforcement ECCU: aquest, aqueix and aquell.

With later development, however, correlations changed. In the case of aci the correlations become weaker, as the determiners (ai)cell and (ai)cest, previously not very common, fell into disuse during the 14th century. The same happened with the adverb ça and with the pronoun ço a short time later (Casanova 2001). In the case of aqui, on the contrary, the relations became stronger. Although at first the determiners could have either simple forms or reinforced forms with $a q u$ in the two first degrees (aquest/est and aqueix/eix), the simple forms (est and eix) lost vitality from the end of the Middle Ages onwards across most of Catalanspeaking territory. Symptomatically they have not survived wherever aqui has been kept and the deictic system is two-term (Casanova 1993). By the end of the Middle Ages and especially in the Modern Age, aqui was better integrated in the systems of demonstratives, which is likely to have led to it gradually displacing $a c i$ and taking on the value of proximity both to the speaker (innovating value) and to the addressee (initial value). ${ }^{25}$ The resulting paradigm is shown in table 10 .

This change in the deictic value also had repercussions on the purely anaphoric value of aqui, which was gradually abandoned as part of a process that had begun in the Middle Ages and that could already be seen in the second half of the 16th century. The purely anaphoric value was basically assumed by the adverb hi (or en if the locative complement indicates the source of the movement).

25. As pointed out above (see footnote 6), different varieties of American Spanish also show a tendency to reduce the three-term system to a two-term system (Sedano 2003; RAE-ASALE 2009: $\S$ 17.8c; Di Tullio 2013: 335-336). In these varieties acá (or aqui) indicates proximity to the speaker and ahi signals distance (including proximity to the addressee) and becomes a variant of the more formal alli, which is also used for contrastive focus. This change is due to the general tendency to reduce three-term systems to two-term systems but it followed a different development than the one described for Catalan. The limitations of this study mean that this topic cannot be covered in detail. Suffice to say that once again, both general and specific factors played their part. In terms of general factors, the second and third degree are defined by negating the speaker's deictic space and they therefore share this feature (see figure 2). In terms of specific factors, in American Spanish the binary adverb series ending in -á (acá and allá) shows a much greater vitality than in Peninsular Spanish, where acá is not commonly used (Sedano 2001: 55- 56; Maldonado 2013: 321; RAE-ASALE: 2009: $§ 17.8 f$ ). To conclude, note that ahi can be related formally with alli, via the palatal feature that shares the $i$ of the former ([a.í]) and the consonant $l l$ of the latter ([a.yí]), and this formal closeness might have favoured their semantic proximity. 


\section{Conclusions}

As has been shown throughout this paper, the systems of space deixis frequently show a certain degree of instability and a tendency towards bidirectional restructuring. On the one hand, the evolution may be from a system of three-way opposition to a two-way one, as occurred in Late Latin and in most Catalan varieties in the Modern Age. On the other hand, the development may involve a change from a two-term to a three-term system, as occurred in Old Catalan, Old Spanish and Old Portuguese.

This two-way tendency is partly motivated by the very nature of deictic oppositions and by the opaque character of space deictics. The parallelism with personal pronouns favours a three-way distinction, in which the first degree is associated with the speaker's deictic space and the second degree is associated with the addressee's deictic space. Conversely, the fact that this objective distinction is not always pertinent, along with the possibility that the demonstratives express progressive degrees of distance, leads to the opposition becoming diluted in some cases. This may result in the demonstrative indicating medial proximity changing to indicate simple proximity.

In addition to factors related to the nature of space deictic systems, systems may be restructured depending on specific factors in each language, and, more particularly, on the paradigmatic relationships set up between the demonstrative forms of each language.

The change from two-term to three-term deixis documented in Old Catalan and Old Spanish can be explained by the possibility that anaphoric demonstratives can take on contextual deictic uses linked to the addressee's space. This contextual meaning became conventionalised very early on in Catalan because the anaphoric adverb aqui was in formal and distributional parallel to the deictic adverbs aci and alli from the outset. In Spanish the process occurred a little later, as first the form ahi had to be analogically recreated from the demonstrative $y$.

The change from three-term to two-term deixis that occurred in Catalan in the Modern Age was again favoured by paradigmatic factors and, specifically, by the loss of vitality of certain formal variants, which left the first-degree adverb $a c i$ increasingly isolated and led to the strengthening of the second-degree adverb aqui. As a result of these correlation changes, aqui gradually displaced aci and took on the value of proximity both to the speaker and to the addressee.

\section{References}

Anderson, Stephen R.; Keenan, Edward L. (1985). «Deixis». In Shopen, Timothy (ed.). Language typology and syntactic description: Grammatical categories and the lexicon, vol. 3. Cambridge: Cambridge University Press, pp. 259-308.

Ariel, Mira (1990). Accessing Noun-phrase Antecedents. London: Routledge.

Bassols, Mariano (1956). Sintaxis latina. Madrid: Consejo Superior de Investigaciones Científicas, 2 vol.

Bello, Andrés (1847 [1988]). Gramática de la lengua castellana. Destinada al uso de los americanos. Tenerife: Cabildo Insular de Tenerife. 
Brucart, Josep Maria (2002). «Els determinants». In: Solà, Joan; Lloret, Maria-Rosa; Mascaró, Joan; Pérez Saldanya, Manuel (eds.). Gramàtica del català contemporani, vol. 2. Barcelona: Empúries, pp. 1435-1516.

Carbonero Cano, Pedro (1979). Deixis espacial y temporal en el sistema lingüístico. Sevilla: Publicaciones de la Universidad de Sevilla.

Casanova, Emili (1993). «Evolució i interferència en el sistema demostratiu català: una explicació». In: Actes del Novè Col·loqui Internacional de Llengua i Literaratura Catalanes, III. Publicacions de l'Abadia de Montserrat: Barcelona, pp. 161-195.

Casanova, Emili (2001). «L'evolució de la construcció ço que > lo que, i d'altres amb lo: Factors i conseqüències». In: Pusch, Claus D. (ed.). Katalanisch in Geschichte und Gegenwart. Satauffenburg Verlag, pp. 39-64.

Cifuentes Honrubia, José Luis (2007). «Verbos deícticos en español», In: ReinheimerRîpeanu, Sanda; Cuniţă, Alexandra; Lupu, Coman; Tasmowski, Liliane (eds.): Studii de Lingvistică şi Filologie Romanică: Hommages offerts à Sandra Reinheimer Rîpeanu. Bucarest: University of Bucharest, 2007, pp. 99-112.

Company, Concepción (2003). «La gramaticalización en la historia del español». In: Company, Concepción (ed.). Gramaticalización y cambio sintáctico en la historia del español. México: Universidad Nacional Autónoma de México, pp. 1-62.

Company, Concepción; Espinosa, Rosa María (2014). «Adverbios demostrativos de lugar». In: Company, Concepción (dir.). Sintaxis de la lengua española. Tercera parte: Preposiciones, adverbios y conjunciones. Relaciones interoracionales. México: Universidad Nacional Autónoma de México/Fondo de Cultura Económica, pp. 129-244.

Cornish, Francis (1999). Anaphora, Discourse and Understanding. Evidence from English and French. Oxford: Oxford University Press.

Corominas, Juan; Pascual, José A. (1980-1991). Diccionario crítico etimológico castellano e hispánico. Madrid: Gredos, 6 vol. 1980-1991.

Cuenca, Maria Josep (2009). «Gramaticalización». In: Ibarretxe-Antuñano, Iraide; Valenzuela, Javier (eds.). Lingüistica Cognitiva. Barcelona: Anthropos, pp. 281-304.

Cuenca, Maria Josep; Ribera, Josep (2013). «Usos y estrategias de traducción inglés-español de los demostrativos en narrativa de ficción». Anuario de Letras. Lingüística y Filología 1: 39-84.

Di Tullio, Ángela (2013). «Ahí y Por Ahí en el español de la Argentina». Anuario de Letras. Lingüistica y Filología 1: 327-356.

Diessel, Holger. (2006). «Demonstratives, joint attention, and the emergence of grammar». Cognitive Linguistics 17: 463-489.

Dixon, R. M. W. (2003). «Demonstratives: A cross-linguistic typology». Studies in Language 27: 61-112.

Eguren, Luis J. (1999). «Pronombres y adverbios demostrativos. Las relaciones deícticas». In: Bosque, Ignacio; Demonte, Violeta (eds.). Gramática Descriptiva de la Lengua Española, vol 1. Madrid: Espasa, pp. 929-972.

Ernout, Alfred (1953). Morphologie historique du latin. París: Klincksieck.

Fillmore, Charles J. (1966). «Deictic categories in the semantics of 'come'» Foundations of Language 2: 219-227.

Gutiérrez Cuadrado, Juan; Pascual, José A. (1995). «Observaciones desde el sentido común a algunas ideas al uso sobre la Historia de la lengua». In: Martí, Sadurní; Feliu, Francesc (eds.). Problemes i mètodes de la Història de la llengua. Barcelona: Cuaderns Crema, 1995, pp. 129-167. 
Guzmán Riverón, Martha; Sáez Rivera, Daniel M. (in press). «Morfosintaxis de los demostrativos indefinidos desde la época colonial a la actual». In: Rojas, Elena; Sánchez Méndez, Juan Pedro (eds.). Morfosintaxis histórica del español de América.

Hopper Paul J.; Traugott, Elizabeth (1993 [2003]). Grammatizalization. Cambridge: Cambridge University Press.

Hottenroth, Priska-Monika (1982). «The system of local deixis in Spanish». In: Weissenborn, Jürgen; Klein, Wolfgang (eds.). Here and there. Cross-linguistic studies on deixis and demonstration. Amsterdam-Philadelphia: John Benjamins, pp. 133-153.

Iso Echegoyen, José Javier (1974). «En torno al sistema deíctico pronominal en latín y su paso a las lenguas románicas». Revista española de lingüística 42: 459-471.

Jungbluth, Konstanze (2004-2005). «Os pronomes demonstrativos do Português Brasileiro na fala e na escrita». Cadernos de Linguagem e Sociedade 7: 83-105.

Kany, Charles (1976). Sintaxis hispanoamericana. Madrid: Gredos

Kleiber, Georges (1995). «D'ici à la et vice versa: pour les aborder autrement», Le gré des langues 8: 8-27.

Lloyd, Paul M. (1993). Del latín al español. Madrid: Gredos.

Maldonado, Ricardo (2013) «Subjetividad en la deixis. El caso de aquí y acá». Anuario de Letras. Lingüística y Filología 1: 285-326.

Monteil, Pierre (1992). Elementos de fonética y morfología del latín. Sevilla: Universidad de Sevilla.

Pascual, José A. (2010). «La aplicación de los corpus a la Filología». In: Bahillo, E.; B. Burgos, B; Iglesias, A. M. (eds.). Interlingüística XXI. Actuales líneas de investigación en el panorama internacional de los jóvenes lingüistas. Valladolid, pp. 31-46.

Pérez Saldanya, Manuel; Rigau, Gemma (2011). «Totz hic viuen ací, e yo sol no yc puc viure!: Una aproximació històrica als adverbis demostratius». In: Lloret, MariaRosa; Pons, Clàudia (eds.). Noves aproximacions a la fonologia i la morfologia del català. Alacant: Institut Interuniversitari de Filologia Valenciana, pp. 459-488.

Pieroni, Sivia (2010). «Deixis and anaphor». In: New perspectives on historical Latin syntax. 3: Constituent syntax: Quantification, numerals, possession, anaphora. Baldi, Philip; Cuzzolin, Pierluigi (eds.). Berlín-Nueva York: De Gruyter Mouton, pp. 389-501.

RAE-ASALE [Real Academia Española; Asociación de Academias de la Lengua Española] (2009). Nueva gramática de la lengua española. Madrid: Espasa, 2 vol.

Ribera, Josep (2008): La cohesió lèxica en seqüències narratives. Universitat de València. Doctoral dissertation. [en línia]. <http://www.tesisenxarxa.net/TDX0917109-143808/index.html> [data de consulta: 31/08/2015].

Ribera, Josep; Cuenca, Maria Josep (2013). «Use and translation of demonstratives in fiction: a contrastive approach (English-Catalan)». Catalan Review 28: 27-49.

Rigau, Gemma (1976). «Anem o venim? ». Els Marges 8: 33-53.

Roca, Francesc (2009). «The left periphery of nominal constructions and the evolution of definite determiners in Romance». In: Rafel Cufí, Joan (ed.) Diachronic Linguistics. Girona: Documenta Universitaria, pp. 495-551.

Sánchez Lancis, Carlos (1990). Estudio de los adverbios de espacio y tiempo en el español medieval, vol. I. Universitat Autònoma de Barcelona, doctoral dissertation. 
Saragossà, Abelard (2004). «El valor dels adjectius demostratius segons les lingüístiques catalana i castellana: problemes i solucions». In: Calvo, Cesáreo; Casanova, Emili; Satorre, Francisco J. (eds.). Quaderns de filologia. Estudis lingüístics 9: 199-243.

Sedano, Mercedes (1994). «Evaluation of two hypotheses about the alternation between aqui and acá in a corpus of present-day Spanish», Language, Variation and Change 6: 223-237.

Sedano, Mercedes (2000). «Variación entre aquí vs. acá y allí vs. allá: la situación en el español hablado de Caracas», Iberoamericana 1: 21-38.

Sedano, Mercedes (2001). «Los adverbios demostrativos en Madrid, Caracas y Buenos Aires ¿Influencia de la direccionalidad?». In: Carbonero Cano, Pedro; Guillén Sutil, Rosario (eds.). Sociolingüistica andaluza 12. Identidad lingüística y comportamientos discursivos. Sevilla: Universidad de Sevilla, pp. 49-62.

Terrado, Xavier (1990). «Sobre la forma de contenido de los adverbios de lugar. Cuestiones de diacronía». Sintagma 2: 55-66.

Teyssier, Paul (1981). «Le système des déictiques spatiaux en portugais aux XIVe, XVe et XVIe siècles». Cahiers de Linguistique Hispanique Médiévale 6: 5-39.

Traugott, Elisabeth Closs (1995). «Subjectification in Grammaticalisation». In: Stein, Dieter; Wright, Susan (eds.). Subjectivity and Subjectivisation. Cambridge: Cambridge University Press, pp. 31-54.

Traugott, Elisabeth Closs (2003). «From subjectification to intersubjectification». In: Hickey, Raymond (ed.). Motives for Language Change. Cambridge: Cambridge University Press, pp. 124-139.

Väänänen, Veikko (1968). Introducción al latín vulgar. Madrid: Gredos.

Vanelli, Laura (2010). «La deissi». In: Salvi, Giampaolo; Lorenzo Renzi (eds.). Grammatica dell'italiano antico. Bologna: il Mulino, pp. 1247-1288.

Vanelli, Laura; Renzi, Lorenzo (1995). «La deissi». In: Lorenzo Renzi; Salvi, Giampaolo; Cardinaletti, Anna (eds.). Grande grammatica italiana di consultazione, vol 3. Bologna: il Mulino, pp. 261-376.

Wheeler, Max W.; Yates, Alan; Dols, Nicolau (1999). Catalan. A comprehensive grammar. London/New York: Routledge.

\section{Corpus}

(Alcoi): Llibre de la Cort de Justícia d'Alcoi (anys 1263-1265). Edited by Maria Àngels Diéguez Seguí. València: Universitat de València, 2011.

(Buen Amor): Arcipreste de Hita, Libro de buen amor. Edited by Alberto Blecua, Madrid: Cátedra, 1992.

(Cavaller): El cavaller i l'alcavota: un procés medieval. Edited by Jaume Riera i Sans. Barcelona: Club Editor, 1973.

(Celestina): Fernando de Rojas, La Celestina. Edited by Dorothy S. Severin, Madrid: Cátedra, 1993.

(Clams): Maria Àngels Diéguez, Clams i crims en la València medieval segons el "Llibre de cort reial de justicia (1279-1321)'. Alacant: Universitat d'Alacant, 2002.

(Corbacho) Alfonso Martínez de Toledo, Arcipreste de Talavera o Corbacho. Edited by Joaquín González Muela. Castalia: Madrid: 1985. 
(Cort): Joan Miralles Monserrat, Un llibre de cort reial mallorqui del segle XIV, vol. II, Mallorca: Institut d'Estudis Baleàrics / Editorial Moll, 1984.

(Crònica): Bernat Desclot, Crònica, vol. V. Edited by M. Coll i Alentorn. Barcelona: Barcino, 1951.

(Diàlegs): Montserrat Alegre Urgell, “Diàlegs” de Sant Gregori. Retranscripció i estudi lingüístic de la versió catalana de 1340. Universitat de Barcelona, doctoral dissertation, 2004.

(Epistolari): Epistolari de Pere III, vol. I. Edited by Ramon Gubert. Barcelona: Barcino, 1955.

(Fets): Jaume I, Llibre dels fets del rei en Jaume, vol. 2. Edited by Jordi Bruguera. Barcelona: Barcino, 1991.

(General Estoria) Alfonso X, General Estoria. Primera parte, vol.1. Edited by Pedro Sánchez Prieto-Borja. Madrid: Biblioteca Castro, 2001.

(Geografia): Josep Iglésies, Pere Gil (1951-1622) i la seva geografia de Catalunya. Barcelona: Institut d'Estudis Catalans, 2002.

(Reintegració): Gabriel Ensenyat Pujol, La reintegració de la corona de Mallorca a la corona d'Aragó (1343-1349), vol. II, Apèndix documental. Mallorca: Editorial Moll, 1997.

(Viatge): «Viatge a l'infern d'en Pere Portes». Llegendes de l'altra vida. Edited by R. Miquel i Planas. Barcelona, 1914, pp. 212-238.

(Victorial): Gutierre Díaz de Games, El Victorial. Edited by Rafael Beltrán Llavador. Madrid: Taurus, 1994.

(Vides): Vides de Sants Rosselloneses, vol. 2. Edited by Charlotte S. Maneikis Kniazzeh and Edward J. Neugaard. Barcelona: Fundació Salvador Vives Casajuana, 1977. 